\title{
The Effectiveness of Course Review Horay Method on Social Sciences Learning Achievement of Visually Impaired Students
}

\author{
Hermawan, Kresna Hertantio Putro, Sugini \\ Universitas Sebelas Maret, Indonesia \\ Email: hermawan@fkip.uns.ac.id
}

\begin{abstract}
This study aims to determine the effectiveness of the Course Review Horay (CRH) method of the social sciences learning achievement of 5th-grade students with visual impairment of SLB A YKAB Surakarta. This research is an experimental research of pre-experimental type research in the form of one group pretest-posttest design. The population in this study are 4 th grade students of visual impairment in SLB A YKAB Surakarta. Data were analyzed by using non-parametric analysis Wilcoxon Signed Rank Test (Wilcoxon Signed Rank Test). The results showed that the average value before using CRH method was 10 , while the mean value after using the $\mathrm{CRH}$ method was 40 . Based on the results of the study, it can be concluded that the Course Review Horay method is effective to improve the social sciences learning achievement 5th-grade students with visual impairment SLB A YKAB Surakarta.

Keywords: course review horay $(\mathrm{CRH})$ method, social sciences learning achievement, students with visual impairment.
\end{abstract}

\section{INTRODUCTION}

Visually impaired children are categorized as children with visual abnormalities. Hallahan et al. (1997) define visual impairment as someone with 20/20 or less vision visibility on the corrected eye (e.g. with glasses) or has a very narrow field of vision with the widest diameter distance, not more than 20 degrees. One problem of visually impaired children at school is their low learning achievement. It happened because the cognitive development of visually impaired children tends to be obstructed compared to normal children in general (Soleh et al., 2011). Tillman (Sunanto, 2005) reveals that visually impaired children have low ability to integrate all facts they have learned, so it seems as if all the visually impaired children's educational experience is kept in a separate room. Thus, the above explanation indicates that impairment can affect the learning achievement of the children.

The facts show that the low learning achievement of visually impaired children at school is caused by internal and external factors. Internal factors are the lack of students' understanding of the concept of the material taught and the lack of students' learning motivation. In addition, the achievement of learning is also influenced by external factors, namely the unsuitable teachers' teaching method with the students' way of thinking and the teachers do not motivate the students to learn (Daryanto \& Raharjo, 2012). It applies to most subjects taught, at school. One of them is the social sciences. Problems found by researchers in the field is that the understanding of 5th-grade students with visual impairment of SLB A YKAB Surakarta about historical figures of Hindu-Buddhism and Islam in Indonesia was low. It was shown by their test score was in the range between 60 until 69 .

Visually impaired students cannot use the regular learning standards and need support and attention in obtaining information. Principles that must be considered in the learning process of visually impaired students is a concrete experience, unification between concepts, and learning by doing (Sunanto, 2005). In order to achieve the learning objectives, Wahab (2007) suggests several teaching methods that suitable with the characteristics of social sciences, namely: lecture method, observation method, discussion method, question and answer method, and simulation method. The learning process in SLB A YKAB has used a certain method on a certain subject, but still dominated by the lecture method. It makes the students have low understanding caused by the teachers' method. Students feel bored and sleepy in the classroom because the method used cannot encourage students to play an active role in learning. Besides, the method cannot generate students' interest in learning.

Adhering to the principles of teaching and learning method for visually impaired students that suitable with the characteristics of subjects, it is expected that learning objectives can be achieved. The researcher chose one method according to the characteristic of social sciences, namely the discussion method.

Discussion method is an activity where people can talk together to share and exchange information about a particular topic. The use of discussion technique cannot be applied as a stand-alone method, because discussion as a teaching method is a tool for students to learn. 
Table 1. Statistic Data of Pretest Score

\begin{tabular}{llr}
\hline & \multicolumn{1}{c}{ Pretest } \\
\hline $\mathrm{N}$ & Valid & 4 \\
& Missing & 0 \\
Mean & & 10.00 \\
Median & & 12.50 \\
Mode & & 15 \\
Std. Deviation & & 7.071 \\
Sum & & 40 \\
Percentiles & 25 & 2.50 \\
& 50 & 12.50 \\
& 75 & 15.00 \\
\hline
\end{tabular}

Table 2. Frequency Distribution of Pretest Score

\begin{tabular}{lcc}
\hline \multicolumn{2}{c}{ Pretest } \\
\hline Valid & 0 & Frequency \\
& 10 & 1 \\
& 15 & 2 \\
& Total & 4 \\
\hline
\end{tabular}

The first activity begins with the planning or also the provision of stepping stones as the basis for discussions such as giving questions, problems, or topics. A suitable learning method appropriate to the method of discussion is the Course Review Horay (CRH) method.

Aris (2014) explains that "Course Review Horay (CRH) is a test of the students' concept of understanding by using a box filled with questions and numbered to compile the answers. The earliest students get the correct sign should immediately shout hooray or other yells". This method can create a festive and fun class atmosphere since every group that can answer correctly can shout hooray (Kasna et al., 2015).

Based on the background, this research is titled "The effectiveness of Course Review Horay (CRH) method on the social sciences learning achievement of 5th-grade students with visual impairment of SLB A YKAB Surakarta."

\section{METHOD}

In this research, the method used is an experimental research method with One Group Pretest-Posttest Design. This method is chosen since the researcher wants to explore the causal relation of giving Course Review Horay (CRH) to the learning achievement of social sciences of historical figures of Hindu-Buddhist and Islam in Indonesia for 5th grade visually impaired students. In this research design of One Group Pretest-Posttest, the experimental unit is treated with two measurements. The first measurement (T0) is performed before treatment is given, and the second measurement (T1) is performed after the treatment is performed (Nazir, 2005).
This research contains two variables, namely: 1) independent variable, namely the use of CRH method, and 2) dependent variable, namely the learning achievement of social sciences material of historical figures of Hindu-Buddhist and Islam in Indonesia. The population in this study are 4 th grade students with visual impairment of SLB A YKAB Surakarta. There was no sample in this study due to the low number of population, thus all students are the subject of the research..

This research used the low number of samples. So the sample is the entire population. Sujarweni (2014) argues that saturated sampling is a technique for determining the sample when all members of the population are used as samples. This is carried out when the population is relatively small, less than 30 people. Thus, the sample of this study is all 4 th grade students with visual impairment of SLB A YKAB Surakarta. Data in this research was collected using a written test of objective, in the form of a short question. This test consists of 20 questions and it was given at the first measurement (T0) before the treatment was given, and the second measurement (T1) was performed after the treatment was carried out. The technique used to analyze the data is nonparametric quantitative analysis techniques by using Wilcoxon Sign Rank Test which is given the symbol Z using SPSS program version 23.

\section{FINDINGS AND DISCUSSION}

\section{Findings}

This research was conducted from 11th to 15th September 2017 at SLB A YKAB Surakarta, Jalan Hos Cokroaminoto no 34 Jebres, Surakarta. Subjects in this research are 5th-grade students with visual impairment of SLB A YKAB Surakarta, with total subjects are 4 students. The results include pretest and posttest score of students obtained during the research. The data on students' test scores in table 1 .

From the statistical data of pretest score in the table 1, it can be seen that the mean score of learning achievement from 4 visually impaired students of $5^{\text {th }}$ grade in social sciences of historical figures of HinduBuddhist and Islamic in Indonesia before treatment was 10.00 , with the highest (maximum) score was 15 , the lowest (minimum) score was 0 , the median score was 12.50 , the frequent (mode) score was 15 , the standard deviation was 7.071, and the total (sum) score was 40. From the data above, it can be presented in the frequency distribution data of the pretest value as in the table 2 . 
Figure 1. Histogram of Pretest Score Result

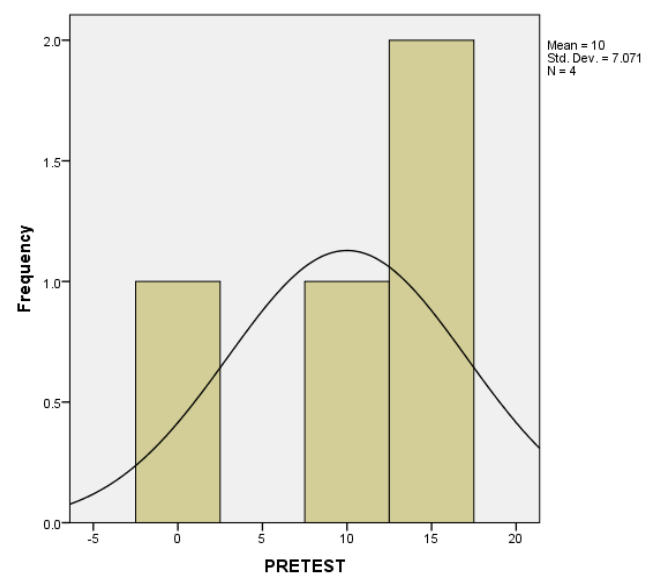

Figure 2. Histogram of Posttest score result

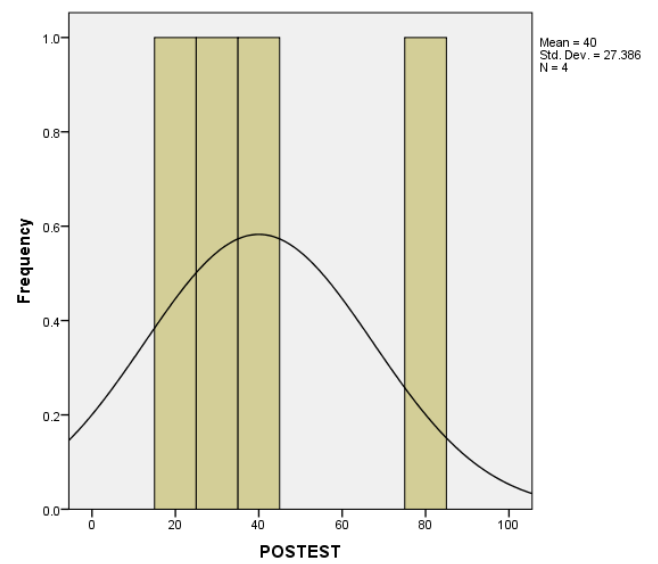

Table 3. Statistical Data of Posttest Score

\begin{tabular}{llr}
\hline \multicolumn{3}{c}{ Statistics } \\
\hline Postest & Valid & 4 \\
$\mathrm{~N}$ & Missing & 0 \\
& & 40.00 \\
Mean & & 30.00 \\
Median & & $20^{\mathrm{a}}$ \\
Mode & & 27.386 \\
Std. Deviation & & 160 \\
Sum & & 21.25 \\
Percentiles & 25 & 30.00 \\
& 50 & 68.75 \\
\hline
\end{tabular}

Table 4. Posttest Value Frequency Distribution

\begin{tabular}{lcc}
\hline & Posttest & \\
\hline & & Frequency \\
\hline Valid & 20 & 1 \\
& 25 & 1 \\
& 35 & 1 \\
& 80 & 1 \\
& Total & 4 \\
\hline
\end{tabular}

Table 5. Comparison Data of Pretest and Posttest Value

\begin{tabular}{cccc}
\hline \multirow{2}{*}{ No } & Students' & \multicolumn{2}{c}{ Score } \\
\cline { 3 - 4 } & Name & Pretest & Posttest \\
\hline 1 & IItial) & 15 & 80 \\
2 & LR & 15 & 25 \\
3 & AF & 10 & 35 \\
4 & MPP & 0 & 20 \\
Average & & 10 & 40 \\
Score & & & \\
\hline
\end{tabular}

Figure 3. Histogram of Pretest and Posttest Score Result

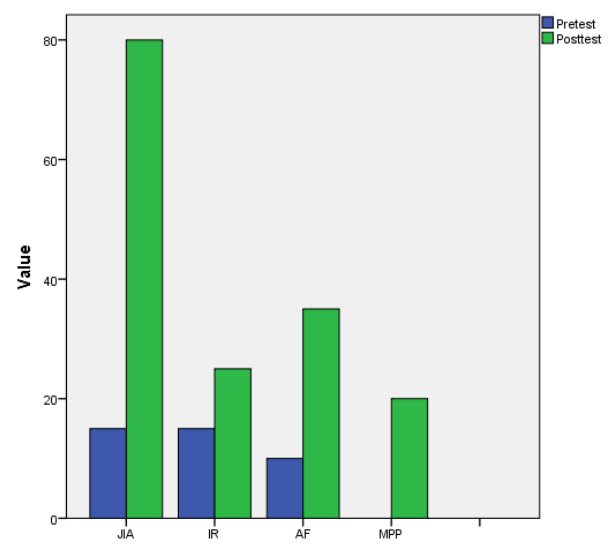

The frequency distribution above can be presented in the form of the histogram graph as figure 1. After treatment, the next step is posttest. Table 3 is the data score of posttest.

From the statistical data of posttest score in the table 3, it can be seen that the mean score of learning achievement of $5^{\text {th }}$ grade students with visual impairment of social sciences of historical figures in the Hindu-Buddhist and Islam in Indonesia after treatment was 40 , with the highest (maximum) score was 80 , the lowest (minimum) score was 20, the median score was 30 , the common (mode) score was 20, standard deviation was 27.386, and the total students' score was 160. The frequency distribution data of the posttest score obtained by the students can be seen in the following table 4 .

The frequency distribution data above can be presented in the form of the histogram graph as figure 2. Based on the pretest and posttest data score, it can be seen that the comparison of pretest score before treatment and posttest value after treatment is as table 5 . Based on data of pretest and posttest score comparison in the table 5 , it can be seen that the average score of social sciences learning achievement of historical figures of Hindu-Buddhist and Islamic in Indonesia before using $\mathrm{CRH}$ method is 10 . Meanwhile, the average score of students' social sciences learning achievement after using CRH method is 40 . The difference between 
the average score indicates that there are different conditions before and after treatment.

The graph as figure 3 is the histogram graph of pretest and posttest score of students' social sciences learning achievement. Based on the result of preexperiment research of one group pretest-posttest design conducted by the researcher, it can be seen that Course Review Horay (CRH) method is effective to improve the social sciences learning achievement of historical figures of Hindu-Buddhist and Islam in Indonesia of 5th grade visually impaired students' of SLB A YKAB Surakarta. It can be proven from the results of data analysis showed that the visually impaired students' social sciences learning achievement increased after being taught by using $\mathrm{CRH}$ method. It can be seen from the average score of students' pretest was 10 and increased to 40 at posttest.

\section{Discussion}

The result of pretest shows that the visually impaired students' social sciences learning achievement is low. This can be seen from the average pretest score of the students is 10 . The low learning achievement of the visually impaired students is due to the cognitive development of the visually impaired students tends to be obstructed compared to the normal child (Soleh et al., 2011), thus they have difficulty in understanding the abstract concept. This opinion is supported by Tilman's statement that children with visual impairment are weak in terms of understanding (Sunanto, 2005). It is known that visually impaired students feel bored and sleepy in the classroom because the method used cannot encourage students to play an active role in learning. Besides, the method cannot generate students' interest in learning. Therefore, the visually impaired children need courage and motivation so that the desire and the courage to participate in learning can increase, so the researcher applies the $\mathrm{CRH}$ method in social sciences learning the material of historical figures of HinduBuddhist and Islam in Indonesia.

In the posttest stage, social sciences learning achievement of visually impaired children increases as researchers used CRH method in learning. This can be seen from the mean pretest score of the students from 10 increased to 40 at posttest. CRH methods can be applied to learning as this method is interesting for students. This method can make learning atmosphere in the classroom to be not monotonous because it is inserted with entertainment so the atmosphere is not stressful, added by "hurray" or other yells that can attract students to learn. In line with the statement, Hamid (2011) stated that the method of learning CRH is one of the fun learning strategies and can make the classroom atmosphere to be cheerful since the students are invited to play while learning. In this case, the students play by shouting "hurray" when they can answer the correct answer from the teacher. CRH method can also increase interest in learning of visually impaired children in learning social sciences, this is supported by the findings from Kasna et al. (2015) in his research entitled the effect of Course Review Horay (CRH) method of student learning achievement, the results showed that students become more concerned when learning, learning conditions become more conducive, and students' enthusiasm for learning increases. Increased student learning interest affects the score of their learning achievement.

CRH learning methods can also encourage children to be more active in learning. The method can make the class more cheerful and fun because the students can interact directly with a group and receive material taught by the teacher. In accordance with (Huda, 2014) states that cooperative learning encourages students to work together in groups to be responsible for their own learning process and to enhance the learning process of group members. By applying the CRH method, visually impaired students have no difficulty in playing an active role in learning, because in CRH methods there is more interaction between individuals in groups than before to help each other in learning the material taught by the teacher. This is supported by (Kasna et al., 2015) that applied the Course Review Horay (CRH) method to improve student activity and learning outcomes. It is known that the students' activity in learning increases because they are not bored during the lesson. In addition, student learning outcomes also increased

\section{CONCLUSION}

Based on the results of research and discussion that has been described previously, it can be concluded that the Course Review Horay ( $\mathrm{CRH}$ ) method is effective to improve 5th grade visually impaired students' social sciences learning achievement of SLB A YKAB Surakarta. This research is expected to become an alternative intervention to enhance the social learning achievement of visually impaired students.

\section{REFERENCES}

Aris, S. (2014). Model Pembelajaran Inovatif dalam Kurikulum 2013. Yogyakarta: AR-ruz Media

Daryanto., \& Rahardjo, M.(2012). Model Pembelajaran Inovatif. Yogyakarta: Gava Media.

Hallahan, D. P., Kauffman, J. M., \& Pullen, P. C. (1997). Exceptional learners: Introduction to special education (7th ed.). Boston: Allyn and Bacon. 
Hamid, S. (2011). Metode Edutainment. Yogyakarta: Diva Press.

Huda, M. (2014). Model-Model Pembelajaran. Yogyakarta: Pustaka Pelajar.

Kasna, I. M. F. P., Sudhita, I. W. R., \& Rati, N. W. (2015). Penerapan Model Pembelajaran CRH (Course Review Horay) dengan Bantuan Permainan Ular Tangga untuk Meningkatkan Hasil Belajar Siswa pada Mata Pelajaran Matematika Kelas II SD. MIMBAR PGSD Undiksha, 3(1).

Nazir, M. (2005). Metode Penelitian. Jakarta: Ghalia Indonesia
Soleh, D. H. P., Abidin, Z., \& Ariati, J. (2011). Pengaruh Metode Jarimatika Terhadap Prestasi Belajar Matematika Siswa Tunanetra Sekolah Dasar Slb Negeri 1 Pemalang. Jurnal Psikologi, 10(2), 115125

Sujarweni, V. W. (2014). Metode Penelitian: Lengkap, Praktis, dan Mudah Dipahami. Yogyakarta: Pustaka Baru Press.

Sunanto, J. (2005). Mengembangkan Potensi Anak Berkelainan Penglihatan. Jakarta: Departemen Pendidikan Nasional.

Wahab, A. A. (2007). Metode Dan Model Mengajar. Bandung: PT. Alfabeta. 